
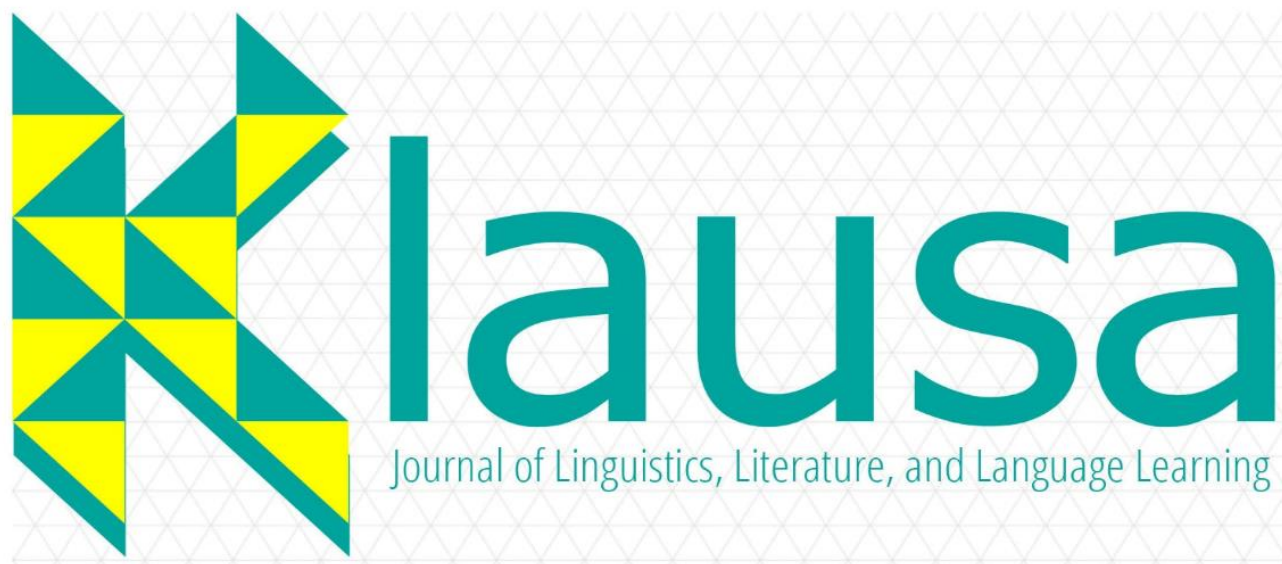

Journal of Linguistics, Literature, and Language Learning
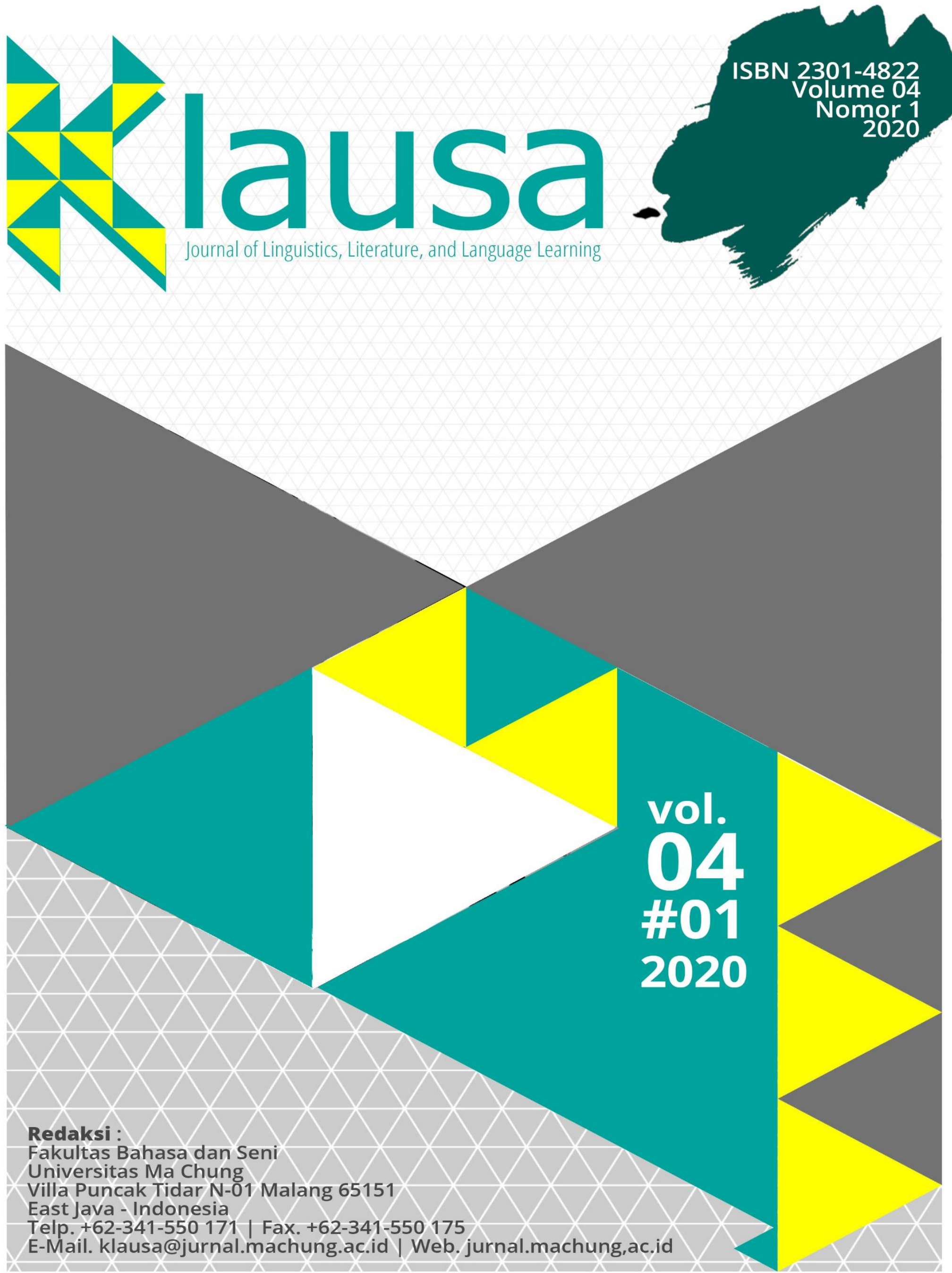
ISSN: $2301-4822(p)$

\section{$\Delta \Delta \| 5 \pi \bigcirc$ Kajian Linguistik, Pembelajaran Bahasa, dan Sastra}

\section{Editorial Team}

\section{Editor-in-Chief}

Journal Manager

Editors

Reviewers

Publisher

Address

Frequency
: Dr. Daniel Ginting

: Wawan Eko Yulianto, Ph.D.

: Prof. Dr. Patrisius I. Djiwandono

Lilis Lestari Wilujeng, M.Hum.

: F.X Dono Sunardi, M.A. Dhatu Sitaresmi, MTCSOL. Anggrah Diah Arlinda, MTCSOL. Yohanna Nirmalasari, S.Pd., M.Pd. Prof. A. Effendi Kadarisman, Ph.D. Sisilia Halim, Ph.D.

Dr. Mundi Rahayu

Dr. Ross Wood

Dr. Leticia Araceli Salas Serrano

: Faculty of Language and Arts

Universitsas Ma Chung

: The Faculty of Language and Arts

Ma Chung University

Villa Puncak Tidar N-01 (65151)

Malang, East Java, Indonesia

Email: jurnal.klausa@machung.ac.id

: Twice a year 


\section{CONTENTS}

FOREWORD

THE STRUCTURE OF COLLOCATION AND ITS TRANSLATION

STRUCTURES IN SUBTITLES OF KURZGESAGT

YOUTUBE CHANNEL

Cynthia Veronika

THE INSEPARABLE NARRATOLOGY AND GENRE IN DISNEY'S ALADDIN (2019): A STRUCTURALIST CRITICISM 11

Sandi Hamim

JUNIOR HIGH SCHOOL PERCEPTION OF COOPERATIVE

GROUP WORK

Puspita Nugraha Wibisono

THE INTEGRATION OF ISLAMIC VALUES IN THE

DEVELOPMENT OF LISTENING COURSE MATERIALS

Mazroatul Ishlahiyah, Mira Shartika

POLA ARGUMEN MAHASISWA JURUSAN PENDIDIKAN BAHASA

MANDARIN

Yohanna Nirmalasari 
ii | DOI: 10.33479/klausa.v4i01 


\title{
POLA ARGUMEN MAHASISWA JURUSAN PENDIDIKAN BAHASA MANDARIN
}

\author{
Yohanna Nirmalasari ${ }^{1}$ \\ ${ }^{1}$ Universitas Ma Chung, yohanna.nirmalasari@machung.ac.id
}

\begin{abstract}
ABSTRAK: The result of reasoning is represented through arguments. Arguments can delivered in writing or spoken. Both types of delivery share elements that espouse the pattern of a speaker in delivering an argument. Such elements are claim, evidence, warrant, qualifier, modality, and rebuttal. Those elements of an argument determine whether an argument is simple or complex. In this research, texts by students were analyzed using the theory of perspective argument as proposed by Stephen Toulmin. The result of this research shows that (1) there is no difference between arguments written by male students and those by female students, and (2) the patterns of argument can be classified into two types, namely, simple and complex.
\end{abstract}

Key Words: Patterns of argument, simple argument, complex argument

\begin{abstract}
ABSTRAK: Bernalar direpresentasikan melalui argumen. Argumen ini dapat diwujudkan melalui argumen tulis ataupun argumen lisan. Kedua argumen ini memiliki unsur-unsur pembangun yang dapat menunjukkan pola penutur bahasa dalam berargumen. Unsur-unsur itu adalah pendirian (PD), data (DT), dasar kebenaran (DK), dukungan (DU), modalitas (MD), dan sanggahan (SG). Unsur-unsur argumen inilah yang membedakan sebuah argumen menjadi argumen sederhana dan argumen kompleks. Di dalam penelitian ini, teks karya mahasiswa dianalisis dengan menggunakan teori argumen perspektif Stephen Toulmin. Hasil penelitian menunjukkan bahwa (1) tidak ada perbedaan pola argumen antara mahasiswa laki-laki dengan mahasiswa perempuan dan (2) pola argumen yang ditemukan dapat diklasifikasikan menjadi dua, yakni pola argumen sederhana dan pola argumen kompleks.
\end{abstract}

Kata Kunci: Pola Argumen, Argumen Sederhana, Argumen Kompleks

\begin{abstract}
ABSTRAK: Proses bernalar direpresentasikan melalui argumen. Argumen ini dapat diwujudkan melalui argumen tulis ataupun argumen lisan. Kedua argumen ini memiliki unsur-unsur pembangun yang dapat menunjukkan pola penutur bahasa dalam berargumen. Unsur-unsur itu adalah pendirian (PD), data (DT), dasar kebenaran (DK), dukungan (DU), modalitas (MD), dan sanggahan (SG). Unsur-unsur argumen inilah yang membedakan sebuah argumen menjadi argumen sederhana dan argumen kompleks. Di dalam penelitian ini, teks karya mahasiswa dianalisis dengan menggunakan teori argumen perspektif Stephen Toulmin. Hasil penelitian menunjukkan bahwa (1) tidak ada perbedaan pola argumen antara mahasiswa laki-laki dengan mahasiswa perempuan dan (2) pola argumen yang ditemukan dapat diklasifikasikan menjadi dua, yakni pola argumen sederhana dan pola argumen kompleks.
\end{abstract}

Kata Kunci: Pola Argumen, Argumen Sederhana, Argumen Kompleks 


\section{PENDAHULUAN}

Proses bernalar merupakan proses yang tentu dialami setiap orang. Proses bernalar lekat dengan bahasa dan pikiran. Bahasa merupakan representasi pikiran, sedangkan pikiran merupakan sumber kemunculan bahasa. Kedua hal ini merupakan dua hal yang selalu berjalan berdampingan. Menurut Dardjowidjojo (2012:2), saat manusia berbahasa, manusia melakukan aktivitas mental yang tertuang dalam wujud bahasa yang dipakai.

Setiap orang yang berpikir dapat dimunculkan melalui bahasa, baik bahasa lisan ataupun bahasa tulis. Hal ini menunjukkan bahwa bahasa dapat diklasifikasi menjadi dua, yakni lisan dan tulis. Walaupun wujudnya berbeda, keduanya tetap melibatkan proses bernalar, hanya saja proses bernalar itu berbeda. Proses bernalar bahasa lisan lebih cepat dibandingkan dengan proses bernalar bahasa tulis karena bahasa lisan menuntut lawan tutur untuk merespons tuturan dari penutur pun sebaliknya. Hal ini tentu berbeda dengan bahasa tulis yang sifatnya lebih permanen sehingga perlu memperhatikan kaidah penulisan. Di dalam bahasa tulis, penutur tidak hanya memiliki kesempatan untuk mengecek kembali kaidah penulisan, tetapi juga memiliki waktu untuk merevisi atau bahkan mengganti gagasannya.

Bahasa lisan antara laki-laki dengan perempuan tentu berbeda. Perempuan akan berujar lebih lengkap dan kompleks dibandingkan dengan laki-laki. Menurut Thomas dan Wareing (2007:124-125), banyak hasil penelitian yang menunjukkan bahwa pria sebenarnya berbicara lebih banyak dari pada wanita ketika berada dalam situasi yang melibatkan kedua gender ini daripada wanita.. Namun, bagaimana dengan bahasa tulis? Apakah bahasa tulis antara laki-laki dengan perempuan juga berbeda? Menurut Langacker (1973), bahasa tulis adalah bahasa yang permanen karena dapat merepresentasikan ide atau gagasan penulis dan lebih mudah untuk dilihat kapan saja. Oleh sebab itu, bahasa tulis yang terwujud dalam tulisan mahasiswa menjadi sarana untuk mengetahui pola argumen yang dikemukakan oleh penulis untuk dihubungkan dengan proses bernalar penulis.

Pola argumen tulis dapat diperoleh dari proposisi yang diujurkan oleh penutur bahasa. Proposisi merupakan maksud kalimat. Menurut Dardjowidjojo (2012:62), proposisi memiliki dua bagian yakni argumen dan predikasi. Argumen merupakan ihwal-ihwal yang dibicarakan, sedangkan predikasi meurpakan pernyataan yang dibuat mengenai argumen. Argumen yang ditemukan di dalam proposisi ini rupanya memiliki pola. Rani, Martutik, dan Arifin (2013) menyatakan bahwa elemen pokok argumentasi ada tiga, yakni pernyataan, alasan, dan pembenaran, sedangkan elemen pelengkapnya adalah pendukung, modal dan sanggahan. Sementara itu, Toulmin, dkk. (1984) memilah pola-pola argumen menjadi enam, yakni claim, data, warrants, qualifiers, rebuttals, dan backing. Di dalam artikel ini masing-masing pola tersebut akan disebut sebagai pendirian (PD), data (DT), dasar kebenaran (DK), dukungan (DU), modalitas (MD), dan bantahan atau sanggahan (DG). Menurut Simon, Enduran, dan Osborne (2006:256), pola argumentasi Toulmin (Toulmin Argumentation Pattern atau TAP) ini sangat cocok bagi seorang peneliti untuk mengidentifikasi argumen dan mengukur kualitas argumen. Oleh sebab itu, di dalam artikel ini hasil dan pembahasan dibahas menggunakan 6 pola tersebut. 
Pola-pola yang ditemukan dalam penelitian ini dapat merepresentasikan pola berpikir penutur. Hal ini sesuai dengan pendapat yang dikemukakan oleh Dardjowidjojo (2012:288) bahwa suatu pikiran yang kompleks dinyatakan dalam kalimat yang kompleks pula. Kompleksitas dalam kalimat yang kompleks ini muncul karena dalam suatu kalimat yang kompleks tentu memiliki proposisi yang lebih banyak, dan di dalam proposisi tersebut terdiri dari argumen yang dapat diamati polanya. Oleh sebab itu, di dalam artikel ini akan dipaparkan tentang pola-pola argumen antara mahasiswa laki-laki dengan perempuan serta untuk menjawab pertanyaan terkait adakah perbedaan antara pola argumen mahasiswa laki-laki dengan mahasiswa perempuan.

\section{METODE PENELITIAN}

Penelitian dalam artikel ini merupakan penelitian kualitatif yang menggunakan kajian analisis tekstual. Kajian ini dipilih karena data yang ditulis oleh mahasiswa dianalisis berdasarkan kategori-kategori yang sudah ditentukan. Wujud dalam penelitian ini ialah unit-unit verbal tulis dalam tulisan mahasiswa yang berupa kalimat. Kalimat tersebut merupakan argumen tulis mahasiswa yang memiliki pola.

Sumber data dalam penelitian ini merupakan teks yang ditulis mahasiswa jurusan Pendidikan Bahasa Mandarin dengan topik yang sudah ditentukan. Sumber data ini dipilih karena mahasiswa jurusan Bahasa Mandarin adalah jurusan yang mendapat mata kuliah landasan pembelajaran bahasa yang mendapatkan materi tentang bahasa dan pikiran.

Penelitian ini menggunakan instrumen utama dan instrumen penunjang. Penelitian menjadi instrumen kunci yang berperan sebagai partisipan aktif karena mengumpul data secara langsung. Selain itu, penelitian menggunakan instrumen penunjang berupa tabel kodifikasi, pedoman analisis data, dan tabel analisis data.

Analisis data penelitian ini dapat dipilah menjadi dua, yakni tahapan analisis data umum dan khusus. Pada tahapan analisis data umum, data direduksi, disajikan, dan ditafsirkan sesuai dengan pola argumennya. Pada tahapan analisis data khusus, data dianalisis berdasarkan fokus penelitiannya. Pertama, data direduksi berdasarkan kriteria data, yakni data dengan topik yang sudah disepakati bersama, data mengandung pola argumen inti, yakni pendirian atau pernyataan (PD). Selanjutnya, data dimasukkan ke dalam tabel analisis data yang dipilah menjadi dua, yakni pola argumen sederhana dan pola argumen kompleks. Kemudian, data dikode. Kedua, data disajikan secara deskriptif sesuai dengan kategori argumen sederhana dan argumen kompleks. Masing-masing kategori tersebut dipilah lagi menjadi argumen yang lemah dan yang kuat. Data yang sudah diklasifikasi dan dikode tersebut kemudian dipaparkan secara deskriptif. Ketiga, data akan diinterpretasi sehingga peneliti dapat menarik sebuah simpulan.

\section{TEMUAN DAN PEMBAHASAN}

Argumen merupakan sebuah pernyataan yang dikemukakan oleh penulis atau penutur bahasa. Menurut Simon, dkk. (2016:4) argumen mengacu pada substansi adanya claim, data, warrant, and backings. Substansi atau unsur inilah yang membedakan pola-pola sebuah argumen.

Oleh sebab itu, pembahasan di dalam artikel ini dapat diklasifikasi menjadi dua, yakni pola argumen sederhana dan pola argumen kompleks. Berikut adalah masing-masing paparannya.

KLAUSA Vol. 4. No. 1 (2020)| 61 


\section{Pola Argumen Sederhana}

Pola argumen sederhana merupakan pola argumen yang hanya terdiri dari unsur argumen inti seperti pendirian, data, dan kebenaran. Pola tersebut dapat diklasifikasi menjadi dua, yakni pola argumen sederhana yang kuat dan pola argumen sederhana yang lemah. Berikut adalah masing-masing paparannya.

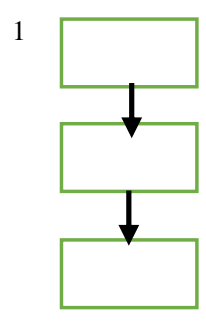

$(\mathrm{Mr} / \mathrm{pas} / 1)$

Pola 1 merupakan contoh pola argumen yang diklasifikasi menjadi pola argumen sederhana karena pada pola tersebut hanya ditemukan tiga unsur argumen, yaitu pendirian, data, dan dukungan. Hal ini sesuai dengan pendapat yang dikemukakan oleh Ardianto (2015) bahwa argumen sederhana merupakan argumen yang struktur argumennya didahului dengan kegiatan mengidentifikasi fakta kemudian ditarik sebuah simpulan atau sebaliknya menarik suatu simpulan kemudian diikuti dengan mengidentifikasi alasan. Pola yang digunakan oleh penulis ini merupakan pola inti dalam sebuah argumen. Berdasarkan pendapat tersebut dapat diketahui bahwa pola yang digunakan oleh penulis untuk mengungkapkan argumen dengan judul pentingnya bahasa Mandarin di Universitas Ma Chung adalah pola yang sederhana.

Pada argumen kutipan 1 tersebut, pendirian yang ditemukan adalah bahasa Mandarin yang saat ini sangat penting dan diminati oleh orang banyak. Kalimat tersebut, penulis ingin memaparkan situasi yang ada dan ingin menegaskan sudut pandang penulis bahwa bahasa Mandarin saat ini sangat penting. Hal ini sesuai dengan teori yang dikemukakan oleh Toulmin, dkk (1984) bahwa claim atau yang disebut dalam penelitian ini sebagai pendirian merupakan pendapat atau pandangan peneliti. Setelah pendirian tersebut, penulis memaparkan data berupa paparan bahwa di dunia kerja, bahasa Mandarin menjadi poin tambahan sehingga dapat mendapatkan penghasilan yang lebih tinggi. Hal ini menunjukkan bahwa kalimat tersebut dikategorikan menjadi data (DT) yang dapat mendukung pendirian bahwa bahasa Mandarin sangat penting. Namun, argumen ini rupanya dirasa penulis masih kurang sehingga penulis menambahkan unsur dukungan (DU) yang menyatakan bahwa ada banyak perusahaan yang mencari lulusan di Universitas Ma Chung untuk bekerja di perusahaan. Kalimat ini dikategorikan sebagai DU karena dapat menjadi landasan untuk mendukung pendirian. Setelah paparan tersebut, penulis memberikan kalimat simpulan yang menyatakan bahwa memilih Universitas Ma Chung merupakan pilihan yang tepat. Berdasarkan kalimat simpulan tersebut dapat diketahui bahwa argumen penulis termasuk ke dalam argumen yang lemah. Walaupun argumennya memiliki unsur utama di dalam argumen, tetapi ada ide yang sumbang, yakni antara judul, pendirian, data, dan dukungan dengan kalimat simpulan. Seharusnya, kalimat simpulan yang dikemukakan oleh 
penulis berkaitan dengan pentingnya bahasa Mandarin di Universitas Ma Chung. Berikut adalah contoh kutipan lain yang dikategorikan sebagai pola argumen sederhana yang lemah.

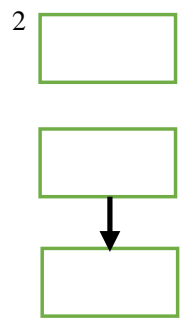

(Cl/pas/2)

Pola 2 merupakan contoh pola argumen sederhana yang lemah. Pola tersebut ditemukan pada teks dengan judul bahasa Mandarin sebagai bahasa kedua dalam kehidupan sehari-hari. Paparan judul tersebut tampak pada unsur argumen yang digunakan oleh penulis. Pada unsur pendirian penulis menjelaskan bahwa bahasa Mandarin ialah bahasa yang digunakan oleh orang Tionghoa. Penulis memperkuat pendirian tersebut dengan menghadirkan unsur dasar kebenaran (DK) bahwa bahasa Mandarin sebagai penghubung kerja sama antara negara dengan negara lain. Setelah dasar kebenaran, penulis menggunakan data. Data yang dihadirkan ini adalah data tentang bahasa Mandarin yang digunakan dalam kehidupan sehari-hari, seperti dalam acara perkumpulan orang Hokkian. Berdasarkan paparan tersebut dapat diketahui bahwa argumen yang dikemukakan oleh penulis adalah argumen yang lemah. Hal ini disebabkan ketidakpaduan antara paragraf yang mengandung pendirian dengan paragraf yang mengandung dasar kebenaran. Selain itu, DK yang dimunculkan oleh penulis tidak relevan dengan DT dan PD. Padahal menurut Setyaningsih (2016), elemen jaminan atau yang dalam penelitian ini disebut sebagai dasar kebenaran (DK) merupakan pandangan pakar terkait dengan masalah penelitian yang relevan dengan data yang disajikan dan pernyataan yang sudah dikemukakan. Berdasarkan pendapat tersebut dapat dinyatakan kembali bahwa antara PD dengan DT memiliki kesamaan proposisi tentang pengguna bahasa Mandarin, tetapi tidak relevan dengan DK yang dihadirkan yaitu tentang bahasa Mandarin sebagai jembatan kerja sama.

\section{Pola Argumen Kompleks}

Pola argumen kompleks merupakan pola argumen yang memiliki banyak unsur pembangun argumen. Selain itu, unsur-unsur argumen itu memiliki unsur pembangun argumen yang lain. Menurut Dawud (2017), kesederhanaan atau kompleksitas struktur argumen didasarkan pada jumlah, kedudukan, dan hubungan unsur-unsur pembangun argumen. Berikut adalah paparannya.

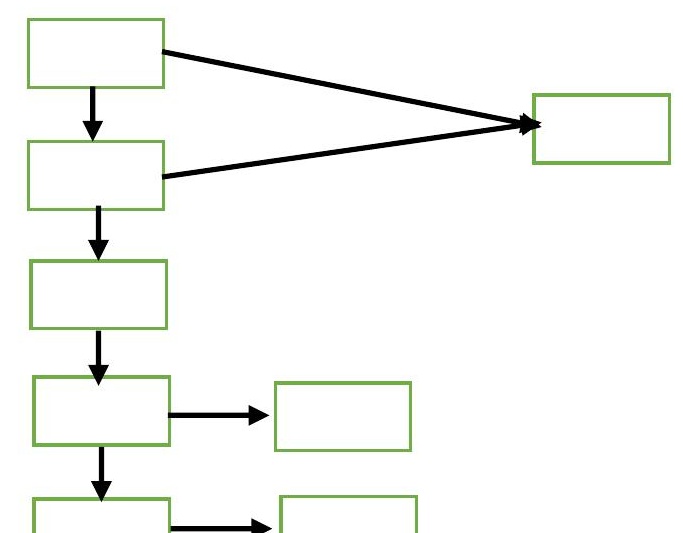

KLAUSA Vol. 4. No. 1 (2020)| 63 


\section{$(\mathrm{Li} / \mathrm{pak} / \mathrm{l})$}

Pola 3 dikategorikan sebagai pola argumen kompleks. Pola ini ditemukan dalam teks yang ditulis oleh mahasiswa perempuan. Pada kutipan ini, penulis menghadirkan PD, DT, DK, DU, MD, dan SG dalam mengembangkan paragraf. Menurut Setyaningsih (2016: 146), sebuah argumen menjadi tidak terbantahkan setelah komponen data (D), komponen jaminan (J), dan komponen pendukung $(\mathrm{P})$ hadir menyertai komponen PP, dengan kata lain kehadiran komponen DT, DK, dan DU yang mendukung PD membentuk sebuah argumen menjadi kuat. Berikut adalah masing-masing paparan komponen tersebut.

Pada paragraf pertama, penulis menggunakan data bahwa bahasa Inggris merupakan bahasa internasional yang saat ini diakui oleh seluruh dunia. Setelah paparan data tersebut, penulis menambahkan DK, yakni di zaman sekarang ada banyak orang belajar bahasa Mandarin karena hampir seluruh perekonomian terbesar dipegang oleh negara Cina. DK ini merupakan DK yang lemah karena tidak didukung dengan bukti yang lain. Menurut Godden dan Douglas (2012: 9), warrant atau DK dapat menjadi sebuah dasar dukungan yang kuat tetapi juga bisa melemahkan sehingga sebuah DK seharusnya didukung dengan bukti empiris yang substansial. Setelah menghadirkan DK, penulis mengungkapkan pendiriannya, yakni bahasa Mandarin dapat menjadi bahasa internasional kedua setelah bahasa Inggris. Paparan ini kembali didukung dengan munculnya fakta bahwa di sekolah-sekolah dasar yang ada di kota besar mulai diajarkan pelajaran bahasa Mandarin. Setelah itu, penulis memunculkan DT berupa paparan bahwa sudah banyak sekolah yang mendatangkan penutur asli dari Cina sehingga lebih mudah untuk berkomunikasi. Data ini berfungsi untuk mendukung argumen penulis terkait banyak orang yang belajar bahasa Mandarin. Hal ini sesuai dengan pendapat Toulmins, dkk. (1984) yang menjelaskan bahwa data merupakan fakta atau bukti yang digunakan untuk mendukung argumen. Selain itu, DT kedua adalah kondisi sekarang bahwa sudah banyak orang tua yang membiasakan berbahasa Inggris dan bahasa Mandarin saat berkomunikasi dengan anak. DU yang muncul ini didukung dengan hadirnya MD bahwa bahasa Mandarin akan menjadi bahasa internasional kedua setelah bahasa Inggris. Penggunaan modalitas ini mendukung pernyataan terkait bahasa Inggris yang menjadi bahasa internasional. Hal ini sesuai dengan pendapat yang dikemukakan oleh Setyaningsih (2016: 140) bahwa komponen keterangan modalitas merupakan piranti pemertahanan pernyataan proposisi karena keterangan modalitas membatasi lingkup pernyataan posisi sehingga pernyataan posisi menjadi semakin spesifik.

Di paragraf akhir, penulis memunculkan sanggahan dengan kalimat jika bahasa negaranya ingin menjadi bahasa internasional, mereka harus memiliki perekonomian yang kuat dan memiliki bangsa yang besar. Kalimat tersebut dikategorikan sebagai sanggahan karena kalimat tersebut 
berlawanan dengan dasar kebenaran yang mengungkapkan bahwa perekonomian terbesar saat ini adalah negara Cina, tetapi pada kalimat sanggahan tersebut penulis menunjukkan bahwa apabila negara Cina harus memiliki perekonomian yang kuat jika ingin menjadikan bahasa Mandarin sebagai bahasa internasional. Dua hal ini merupakan argumen yang berlawanan sehingga argumen ini dikategorikan sebagai argumen yang lemah. Hal ini selaras dengan teori yang dikemukakan oleh Walton (2012:5) bahwa sebuah simpulan seharusnya merupakan hasil dari argumen awal apabila hanya ada satu argumen pendukung saja sehingga dapat mengalahkan argumen yang berlawanan dengan pendirian. Oleh sebab itu, secara unsur pola argumennya, kutipan ini dikatakan sebagai argumen yang tidak terbantahkan atau kuat, tetapi dilihat dari koherensi antar unsur argumennya, argumen ini adalah argumen yang lemah. Selain paparan tersebut, berikut adalah contoh argumen kompleks lain.

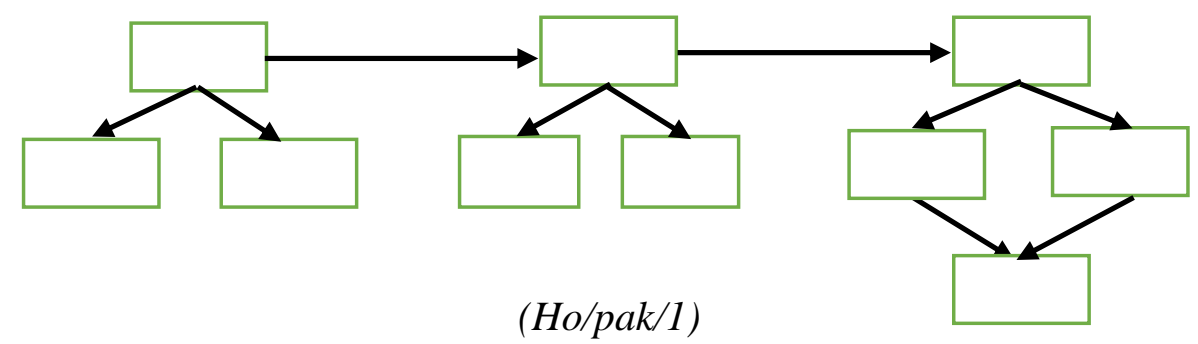

Pola 4 dikategorikan sebagai pola argumen kompleks. Pola ini ditemukan di dalam teks yang ditulis oleh mahasiswa laki-laki. Pada paragraf pertama, penulis memunculkan DT, yakni di era globalisasi ini banyak warga negara yang datang ke negara lain untuk mencari pekerjaan maupun sekadar berkunjung untuk berlibur. Dari data yang dimunculkan ini, penulis memunculkan dukungan (DU) bahwa keterbatasan manusia dalam berbahasa akan menghambat perkembangan di era globalisasi ini. Setelah itu, penulis memunculkan DT yang mendukung DU yang mengungkapkan bahwa banyak universitas yang membuka jurusan bahasa untuk memenuhi kebutuhan dunia saat ini, salah satunya adalah bahasa Mandarin. Selanjutnya, penulis memunculkan pendirian bahwa bahasa Mandarin sangat diminati. Setelah itu, penulis memunculkan DU yaitu banyak pengusaha Tiongkok yang meluaskan bisnisnya ke Indonesia $\left(D_{1}\right)$, kebutuhan pariwisata $\left(D_{2}\right)$, dan pendidikan $\left(D_{3}\right)$. Hal ini selaras dengan pendapat Setyaningsih (2016:140) yang mengemukakan bahwa DU berfungsi untuk memperkuat pernyataan posisi atau PD.

Pada paragraf yang kedua, penulis memunculkan pendirian lagi bahwa bahasa Mandarin sangat penting di dunia kerja. Hal ini didukung dengan DT bahwa di era sekarang banyak perusahaan yang menghendaki karyawannya menguasai bahasa Mandarin dan bahkan orang yang biasa berbahasa Mandarin sengaja dicari oleh perusahaan. Selanjutnya, penulis memberikan $\mathrm{DT}_{2}$ bahwa Indonesia memiliki kondisi alam yang menakjubkan sehingga dapat mendorong orang luar negeri khususnya Tiongkok untuk melihat Indonesia. Pada kalimat selanjutnya, penulis menggunakan DU untuk memperkuat argumennya dengan cara menunjukkan fakta bahwa kondisi masyarakat Indonesia saat ini tentu tidak dapat berkomunikasi dengan baik sehingga pemandu wisata yang bisa berbahasa Mandarin sangat banyak dicari. Berdasarkan paparan tersebut dapat 
diketahui bahwa tidak semua DU menjadi komponen pendukung antara PD dengan DT. Oleh sebab itu, dapat dinyatakan bahwa argumen yang dikemukakan oleh penulis adalah argumen yang lemah karena ada beberapa unsur argumen yang tidak berhubungan dan belum selesai. Selain argumen tersebut, berikut adalah contoh pola argumen lemah yang lain.

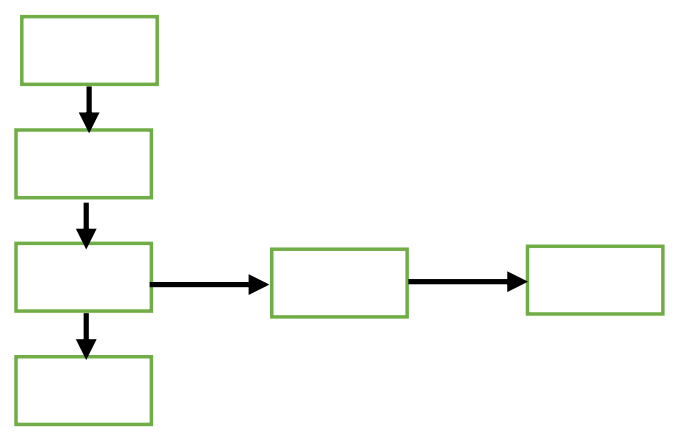

$(\mathrm{Wi} / \mathrm{pak} / 1)$

Pola dikategorikan sebagai pola argumen yang kompleks karena memiliki banyak unsur argumen. Pola ini ditulis oleh mahasiswa perempuan yang memulai paragraf pertamanya dengan sebuah pendirian bahwa bahasa Mandarin sangat wajar untuk digunakan di era globalisasi ini. Pendirian ini didukung dengan data (DT). Data yang digunakan oleh penulis adalah sebuah kondisi bahwa sebagian besar orang dari negara di luar Asia seperti Amerika Serikat dan Inggris yang sudah menggunakan bahasa Mandarin. Hal ini selaras dengan pendapat Setyaningsih (2016:140) bahwa DT dapat berupa hasil wawancara, hasil observasi, hasil uji eksperimen, hasil uji statistik, dan hasil analisis dokumen terkait masalah penelitian. Dalam hal ini, penulis menggunakan data yang berasal dari observasi pribadinya sendiri. Setelah data tersebut, penulis mencoba menambahkan unsur DU bahwa penggunaan bahasa Mandarin melaju pesat karena bahasa Mandarin memasuki berbagai bidang seperti bidang teknologi, ekonomi, industri, dan pendidikan. DU ini diperkuat dengan hadirnya $\mathrm{DT}_{1}$ bahwa saat ini bahasa Mandarin merupakan mata pelajaran di berbagai sekolah menengah. Selain itu, penulis juga memperkuat argumennya dengan $\mathrm{DT}_{2}$ bahwa saat ini banyak mahasiswa yang mengambil jurusan bahasa Mandarin. Namun, jika dikaitkan dengan DU awal, tampak adanya lompatan gagasan pada kalimat tersebut, sehingga hubungan antara DU dengan DT tidak koherensi. DT ini diperkuat oleh penulis dengan menghadirkan DU, yakni fakta di Universitas Ma Chung yang mewajibkan semua mahasiswa untuk belajar bahasa Mandarin. Pada paragraf akhir, penulis menghadirkan MD meskipun bahasa Mandarin sulit untuk dipahami, tetapi kita tahu bahwa bahasa Mandarin akan berguna ke depannya. Kalimat tersebut menunjukkan bahwa penulis ingin menegaskan dan meyakinkan pembaca bahwa walaupun bahasa Mandarin sulit, tetapi hal itu tidak akan merugikan. Hal ini menunjukkan adanya kemungkinan yang menguatkan kondisi saat ini. Berdasarkan paparan tersebut dapat disimpulkan bahwa semua pola argumen yang digunakan oleh mahasiswa merupakan pola argumen kompleks yang lemah. Hal ini bisa terjadi karena ada banyak lompatan ide yang ditemukan di dalam teks. Selain itu, ada beberapa unsur argumen yang tidak memiliki koherensi. 


\section{SIMPULAN DAN SARAN}

Penelitian ini memiliki dua simpulan yang sesuai dengan fokus penelitian. Fokus penelitian pertama terkait perbedaan pola argumen antara mahasiswa laki-laki dengan mahasiswa perempuan. Fokus penelitian kedua terkait pola argumen mahasiswa laki-laki ataupun pola argumen mahasiswa perempuan. Berikut adalah masing-masing paparannya.

Pertama, hasil penelitian menunjukkan bahwa tidak ada perbedaan pola argumen yang khusus antara argumen mahasiswa laki-laki dengan mahasiswa perempuan. Hal ini ditandai dengan tetap hadirnya unsur pendirian dan data di dalam semua argumennya. Selain itu, hasil penelitian juga menunjukkan bahwa tidak ada keajekan pola argumen yang sama antara mahasiswa laki-laki dengan perempuan.

Kedua, hasil penelitian menunjukkan bahwa pola argumen mahasiswa baik laki-laki ataupun perempuan dapat dikategorikan menjadi dua, yakni pola argumen sederhana dan kompleks. Masing-masing jenis argumen tersebut dapat diklasifikasi menjadi argumen yang lemah dan argumen yang kuat. Jenis-jenis argumen ini pun tidak berkaitan dengan jenis kelamin penulis.

\section{DAFTAR RUJUKAN}

Dardjowidjojo, S. (2012). Psikolinguistik: Pengantar Pemahaman Bahasa Manusia. Jakarta: Yayasan Pustaka Obor Indonesia.

Dawud. (2017). Kecerdasan dalam Pembelajaran Bahasa Indonesia. Makalah dipresentasikan pada seminar Nasional Nitisastra II, Mei 2017, Malang.

Godden, D.M. \& Douglas W. (2012, July). Advances in the Theory of Argumentation Schemes and Critical Questions. International Journal of Cognitive Informatics and Natural Intelligence. https://www.researchgate.net/publication/262394690.

Langacker, R.W. (1973). Language and Its Structure: Some Fundamental Linguistic Concepts. San Diego: Harcourt Brace Jovanovich Publishers.

Rani, A., Martutik, dan Arifin, B. (2013). Analisis Wacana: Tinjauan Deskriptif. Malang: Surya Pena Gemilang.

Setyaningsih, Y. (2016). Pola Argumen Paragraf Argumentatif pada Artikel Jurnal Terakreditasi Bidang Ekonomi (Persepektif Stephen Toulmin). Jurnal Adabiyyat, Vol XV, 2, 136-156.

Simon S., Erduran S. and Osborne J. (2006). Learning to Teach Argumentation: Research and Development in the Science Classroom, International Journal of Science Education, 28, $235-260$.

Thomas, L. \& Wareing, S. (2007). Bahasa, Masyarakat, dan Kekuasaan. Jakarta: Pustaka Pelajar.

Toulmin, S., Rieke R., dan Janik A. (1984). An Introduction to Reasoning. New York: Collier Macmillan Publisher.

Toulmin, S. (2003). The Uses of Argument. New York: Cambridge University Press. Walton, D. (2014, Juni). Finding the Logic in Argumentation. Research Gate. https://www.researchgate.net/publication/256042018.

Warrick,B. dan Inch, E.S. (1994). Critical Thinking and Communication. New York: Macmillan Publishing Company. 
68 | DOI: 10.33479/klausa.v4i01 